\title{
Between Dualism and Immanentism Sacramental Ontology and History
}

\section{Enrico Beltramini}

Citation: Beltramini, Enrico. 2021. Between Dualism and Immanentism Sacramental Ontology and History. Religions 12: 47. https://doi.org/ 10.3390rel12010047

Received: 3 December 2020

Accepted: 23 December 2020

Published: 11 January 2021

Publisher's Note: MDPI stays neutral with regard to jurisdictional clai$\mathrm{ms}$ in published maps and institutional affiliations.

Copyright: () 2021 by the author. Licensee MDPI, Basel, Switzerland. This article is an open access article distributed under the terms and conditions of the Creative Commons Attribution (CC BY) license (https:// creativecommons.org/licenses/by/ $4.0 /)$.
Department of Philosophy and Religious Studies, Notre Dame de Namur University, Belmont, CA 94002, USA; ebeltramini@ndnu.edu

\begin{abstract}
How to deal with religious ideas in religious history (and in history in general) has recently become a matter of discussion. In particular, a number of authors have framed their work around the concept of 'sacramental ontology,' that is, a unified vision of reality in which the secular and the religious come together, although maintaining their distinction. The authors' choices have been criticized by their fellow colleagues as a form of apologetics and a return to integralism. The aim of this article is to provide a proper context in which to locate the phenomenon of sacramental ontology. I suggest considering (1) the generation of the concept of sacramental ontology as part of the internal dialectic of the Christian intellectual world, not as a reaction to the secular; and (2) the adoption of the concept as a protection against ontological nihilism, not as an attack on scientific knowledge.
\end{abstract}

Keywords: sacramental ontology; history; dualism; immanentism; nihilism

\section{Introduction}

A specter is haunting the historical enterprise, the specter of 'sacramental ontology.' The specter of sacramental ontology is carried by a generation of Roman Catholic and Evangelical historians as well as historical theologians who aim to restore the sacred dimension of nature. ' Sacramental ontology' is an ontological perspective that incorporates the notion that the material and the spiritual coexist in the reality of the past. C.S. Lewis, who knew and loved the medieval 'cosmos,' describes it as "tingling with anthropomorphic life, dancing, ceremonial, a festival not a machine" (Ward 2007, p. 24). It was an organic whole, ordered from within, animated by a hierarchy of souls, perhaps even by a 'world soul' (in the sense of 'principle of order'). It meant that nature possessed a sacred and spiritual value, by virtue of its creation by God and by the immanent presence of God within it. This notion is particularly relevant in the case of history, in all its forms, including religious history. Recently, historians Andrew Willard Jones and Brad Gregory adopted the concept of 'sacramental ontology' in their work (Jones 2017; Gregory 2012a). Not surprisingly, their writings have prompted a barrage of questions, complaints, and criticism. ${ }^{2}$ The criticism has focused on the historical themes addressed in their books, but mostly on their approach and their method, in which the secular is no longer the accepted natural background of historical research. In brief, their work has been received as a form of apologetics and a return to integralism (rejection of modernism), and ultimately homologated to that of Christian fundamentalists. ${ }^{3}$ Another stream of criticism, however, has focused (only with

1 Here I refer to Andrew Willard Jones, Brad S. Gregory, John Milbank, Dennis M. Doyle, Hans Boersma, Brian Daley, and Bryan C. Hollon.

2 In the case of Gregory's book, highly appreciative remarks (especially from the Catholic side) are countered by rather dismissive, sometimes even venomous reviews (by Ian Hunter, James Chappel, Mark Lilla, and others), as well as by more balanced critiques (those of Peter Gordon, Victoria Kahn and Adrian Pabst, for instance) (see Hunter 2013; Chappel 2013; Lilla 2013; Gordon 2013; Kahn 2013; Pabst 2013).

3 I refer to Mark Lilla's comment that "over the past thirty years" this genre [to which Gregory's book belongs] has been adopted by a new group of "anti-modern Catholics (and some Anglicans) on the left and the right, from members of the post-modern Radical Orthodoxy movement in Britain to conservative American writers around First Things magazine" (see Lilla 2013, p. 49). Kenneth G. Appold refers to Gregory's work in terms of "preecumenical Catholic apologetics" (see Appold 2013). William T. Cavanaugh writes that "Gregory seems to be arguing that when the West turned from an integrally Catholic society, it took a wrong turn" (see Cavanaugh 2013). 
regard to Gregory's book) on the deeply pessimistic evaluation of the modern age, as if the non-sacramental world of modernity had forced people "into a tale of inevitable futility and decline," as if the history of modernity could be seen as a 'history of decline' (Verfallsgeschichte) (Lundin 2012, p. 413).

In this article, I am not interested in addressing Jones' and Gregory's books or the debate they initiated. I prefer to offer a context in which such a debate can grow. More specifically, I aim to contribute in two ways to the debate on sacramental ontology and history: first, I explain where this 'Christian instinct' to recover a sacramental worldview, then inject it into history, comes from; second, I identify the target of this recovery of sacramental ontology, or what this Christian instinct is against. I believe that a better understanding of the origin of the concept and the motivation of some authors to use it can help the debate enormously, particularly with regard to the criticism of fundamentalism and anti-modernism. To briefly anticipate my argument, the recovery of a sacramental worldview is the result of the works of Christian theologians, philosophers, and historians who have questioned the idea of the 'two-story universe,' the unintended consequence of the Protestant Reformation (according to Brad Gregory), a deviant interpretation of Scholasticism within Catholicism (according to Henri de Lubac), an evolution within the thought of the elites (John Milbank), or a development within the culture of the masses (Charles Taylor) (de Lubac 1946; Milbank 1997b; Taylor 2007). In a two-story universe, one is the so-called 'real world' (physical, material, world), which is neutral territory, inherently devoid of religious content. Spiritual things, including God, are relegated to the second story and somehow cordoned off from daily existence. Sacramental ontology is the unification, in distinction, of the two stories in one single world. The target of this recovery, then, is the development of a remedy to the incipient nihilism, a nihilism that is ontological in character and affects the whole reality, including the very existence of the historical enterprise as a respectable vehicle to study the past. In this regard, sacramental ontology operates as a counter-ontology against the mounting challenge of ontological nihilism. I show that Gregory's Unintended Reformation designs an historical arc from the prehistory of modernity to the postmodernity of transhumanism, the latter being the target of Gregory's polemics. Accordingly, this paper is divided in two parts: (1) a synthetic description of the historical and theological background of the emergence of the concept of sacramental ontology, and (2) discussion of sacramental ontology as an antidote to ontological nihilism in history.

\section{Background}

The term 'sacramental ontology' was introduced into scholarly conversation during the assessment of the theological and historical theological work of Catholic priest Henri de Lubac. A generation of scholars addressed his imposing legacy in search of the real core of his life's output. According to John Milbank, this core can be identified in de Lubac's account of nature and the supernatural, as articulated in his 1946 book Supernaturel: Etudes historiques (Milbank 2005b, p. 5). In his book, de Lubac formulated the most authentic and enduring reaction of the hierarchical duality between nature and grace, nature and the supernatural, or, to put it differently, of the theory of the two-store universe. Other theologians have developed Milbank's ontological interpretation of de Lubac's work. Denis Doyle is responsible for the term 'sacramental ontology;' Hans Boersma borrows Doyle's terms and argues that sacramental ontology concerns the "sacramental character of all created existence". ${ }^{4}$ Thus, 'sacramental ontology' is a derivative of de Lubac's account of nature and the supernatural, which is the theme I turn to now.

In the period between the two world wars, a group of French and German-speaking theologians, although far from being a tightly organized school, developed the conviction that Roman Catholic theology needed to enter into dialogue with the secular thought world and the daily life of the Church of their times. The majority of these theologians in 
the early and mid-20th century, Henri de Lubac, Jean Daniélou, Hans Urs von Balthasar, Yves Congar, Marie-Dominique Chenu, and Louis Bouyer, adopted Maurice Blondel's non-adversarial approach to modernity, that is, science and modern intellectual culture need to be incorporated into Catholic tradition. Blondel (1861-1949) was a philosopher, not a theologian, who produced his most influential works between 1893, the year when his doctoral thesis (L'Action) was published, and 1909-1910, the years when a set of articles was published under pseudonymous in Annales de philosophie Chrétienne (Blondel 1950; Blondel 1909-1910). ${ }^{5}$ Blondel was a convinced Catholic and a religious man who seriously considered becoming a priest, although he decided against this course. He was also a French philosopher familiar with modern philosophical vocabulary and methods. He wondered if being a loyal citizen of the anticlerical state and a devout member of the integralist Roman Catholic Church was a sustainable condition for French Catholics. He considered if the separation between reason and faith could be considered a permanent, inevitable collateral effect of modernity, or rather modernity could be re-imagined to the point that a unity between faith and reason can be re-established.

One of the points of departure of Blondel's philosophical enterprise was the reconnection of dogma and history, against the tendency, in play since the end of the Middle Ages, to keep them separate. He accomplished this reconnection by means of articulating an influential notion of tradition. The word 'tradition' comes from the Latin verb tradere; it means 'to pass or hand something on.' In this basic sense, tradition is the process of handing on the faith; in pre-Vatican II Catholicism, tradition was the second distinct source of revelation after Scripture (or, in a less dominant interpretation, a second mode of expression of revelation). Blondel was not a specialist in the history of tradition; nevertheless, he was cached in the middle of the modernist crisis and found imperative to clarify the meaning of tradition. 'Modernism' is the negative label conceived by its opponents of an historical movement of thought within Catholicism. This movement of thought, which developed in Europe and the United States, had its epicenter in France and exercised its influence during the first decade of this century, until its condemnation in 1907 by the Encyclical Pascendi Dominici gregi, an authoritative papal statement. Modernism was a premature, and ultimately erroneous from the doctrinal standpoint, but genuine intellectual movement within Catholicism. The aim of this movement was to break the cultural isolation of the Church and confront the world of modern philosophy, critical historical scholarship, and science. At a much deeper level, modernism was an unintentional, but unequivocal challenge to traditional Catholicism, its isolation, its static doctrinal formulas, and ultimately its authoritarian structure. Theologian Roger Haight explains that the crisis between modern world and Catholic theology was inevitable.

Given this situation, once the principle of immanence and the presuppositions of man's autonomy began to be taken seriously in the domain of philosophy, the idea of a supernatural truth imposed on man from the outside and solely through a church authority became ambiguous. On the level of historical science, when the method and findings of biblical criticism began to be recognized, certain historical data seemed to contradict this authority. When this modern world came crashing in on Catholic theology, crisis was born (Haight 1974, p. 661).

The modernist crisis materialized in a series of debates about apologetics, biblical criticism, and the question of dogma. It was in the discussion around the question of dogma that Blondel articulated a religious historical method that became normative for the next generation of Roman Catholic theologians.

Blondel's entry into the question of dogma debate was in 1904 through a set of articles published in La Quinzaine. They were later published under the title Histoire et Dogme:

5 Blondel published a series of essays, in 1909 and 1910, under the pseudonym Testis (Blondel 1909-1910). These essays were then republished as a single volume entitled Catholicisme Social et Monophorisme: Controverses sur les Méthodes et les Doctrines. 
Les lacunes philosophiques de l'exégèse modern (Blondel 1956). ${ }^{6}$ In the introduction, Blondel clarified that the object of his analysis was Christian beliefs (dogma) in juxtaposition with Christian facts (history). The Blondelian perspective was based on the assumption that in the controversy between traditionalists and modernists, both sides were wrong. He labeled the traditionalist option alternative, 'extrinsicism,' and the modernist alternative, 'historicism.' In Blondel's opinion, extrinsicism and historicism were the two streams of thought competing to bridge the gap between human history and divine revelation. Extrinsicism interpreted dogma as based on divine revelation given once and for all in its entirety at a given point in history; from this point on, dogma is conceived as an unchanging and unchangeable set of formulations, statements, unrelated to history and subject to the sole authority of the Church.

Historicism stressed historical facts as the primary source of truth; however, in Blondel's opinion, historicism is a closed system that develops with no regard to the Christian dogma, which is the supernatural datum. It is important to note that in the context of historicism, 'history' is understood as modern and objective critical-historical method in biblical exegesis. The single most important figure in this critical-historical method in biblical exegesis was Alfred Loisy. Blondel and Loisy exchanged letters in early 1903; in this exchange, they clarified their positions (Marlé 1960). Loisy was adamant that he was writing as a historian; as an historian, he argued, his conclusions depended exclusively on a critical examination of Scripture. As an historian, he operated within the narrow ream of historical data, according to historical methodologies, and intentionally leaving the whole reality of the religious to theological investigation. More generally, however, Loisy rejected the idea that Christian faith may be reduced to pure fideism, the acceptance of authoritative doctrinal pronouncements of the magisterium of the Church. As theologian William A. Scott, SJ, notes in his comment to Loisy's position, "a distinction is introduced between faith, which is a matter of voluntary adhesion to a doctrine, and history, which is the realm of reason, of fact. There is no necessary correlation between these two orders of faith and history" (Scott 1966, p. 385). For all that, Blondel suspected that, with his history exclusively based on facts and his historical method excluding the supernatural, Loisy was compromising Christianity.

Blondel offered an interpretation of tradition as a work in progress, a dynamic expression of the ever-changing understanding of the revelation as the Church interprets the Scriptures in the light of Christian experience. The Blondelian perspective was based on the assumption that dogma and history are interdependent; to put it differently, theological formulations and historical facts are inherently valuable, but need to be seen not as autonomous but rather interdependent of each other and at the service of tradition. The relationship that exists between Christian revelation and human history is neither one of independence of revelation from "all the sediment accumulated by centuries of human thought" nor one of dependence of revelation on the investigations of historical investigation. Each option is an incomplete portrait of the Christian reality (Blondel 1964, pp. 217-18). Christian reality is a "synthesis of dogma and facts ... a synthesis of thought and of grace, a union of man and of God" (Ibid.). Christian reality is the mutual relationship and interpenetration of nature and grace, the created world and the eternal Logos. In the words of the Apostle Paul, "He is before all things, and in him all things hold together" (Colossians 1:17).

Henri de Lubac (1896-1991) was an avid reader and sincere admirer of Blondel. He studied the two alternatives that Blondel rejected, extrinsicism and historicism, and applied it to the problem of grace and nature. As is well known, de Lubac's Surnaturel' focuses particularly on the danger of extrinsicism, which is the idea of a realm of the supernatural that is separated from an independent realm of nature (previously mentioned as two-story

6 A series of three articles in La Quinzaine 56 (January-February 1904) entitled, "Histoire et dogme, les lacunesphilosophiques de l'exégèsemoderne," and one article in Bulletin de littérature ecclésiastique de Toulouse (February-March 1905) entitled, "De la valeur historique de dogme." All four articles have been reprinted in Blondel (1956). All subsequent citations of Blondel are drawn from the English translation (Blondel 1964). 
universe). De Lubac is the one who launched the decisive attack on the traditional interpretation of Aquinas by Cardinal Cajetan which was distorting Christian thought. Iberian Scholasticism (Scholasticism henceforth) is a 17th-century re-elaboration of Thomist corpus. Articulated by Catholic theologians Thomas de Vio Cajetan (1468-1534) and Francisco Suarez (1548-1617), Scholasticism would become dominant in Catholic theology and also in some rings of Protestantism. According to Cardinal Kasper, it established a "timeless, unified theology that provided a norm for the universal church" (Kasper 1989, p. 1). In a series of books published across a span of 20 years before the Second Vatican Council, de Lubac makes a persuasive case that Cardinal Cajetan and Scholasticism misread Aquinas (de Lubac 1946, 1998, 2008). In an attempt to defend nature from Lutheranism-especially the doctrine of the total corruption of human nature by original sin, and later, the problem the supernatural from the attack of Enlightenment humanism-Scholastic theologians separated the order of the supernatural from the natural order of reason. The supernaturalistic character of Catholic theology, severed as it was from effective engagement with nature, brought to a kind of extrahistorical Catholicism. With no connection to the supernatural order, Catholicism at the level of natural order was a private interior practice or an external social observance. The first option was the Kant-Kierkegaard line of thought on the limit of reason. Accordingly, theologians located faith to the privacy of one's individual soul. The second option was the social space, especially the social doctrine of the Church. Thus, Catholic theology unintentionally ignited total secularization, embraced an unconstrained criticism against the dualistic epistemology of modern thought, and offered the idea of faith as an 'extrinsic' addition.

The separatist theology of the supernatural and natural orders was an imperceptible and yet decisive departure from the patristic-medieval conception of unity of natural and supernatural. In fact, the distinction between natural and supernatural introduced by Scholastic theologians ruined the patristic-medieval understanding of history as operating according to an inner orientation toward a supernatural destiny. Thus, Scholasticism rendered eminent service to Catholicism, defending the gratuity of the supernatural order of grace from the natural order of reason (a reason that is purified from added supernatural end), at the same time effecting a separation between the supernatural and reason that eventually came to be taken for granted. In a theological system based on the separation between the supernatural and the natural, the Catholic Church prided itself on being above history, while the natural world became a place divorced from God.

In the early 20th century, the traditional interpretation of Aquinas by Cardinal Cajetan emphasized the discontinuity between nature and grace, to the point that the notion of the state of pure nature was generally accepted. In this way, nature was isolated from grace, the world from God, and philosophy and science from theology. De Lubac argued that the option of a purely natural condition does not exist and in fact sustained the opposite, that is, the continuity between the natural and grace: the interpenetration of nature and grace. At this regard, Hans Urs von Balthasar will say that de Lubac attempts to recover the ancient intuition that the transcendent is already contained in the immanent.

[de Lubac's goal] was to burst the bonds of the whole sphere of nature to reach that of revelation-which had already occurred in fact and which indeed was the very foundation of the whole sphere of nature in the first place (von Balthasar [1951] 1992, p. 341).

De Lubac's goal consists of recovering an outlook on life that brings together natural philosophy and supernatural religion. He insisted repeatedly that there is an essential heterogeneity, with real continuity, between the natural and supernatural orders. Accordingly, his aim is to articulate a Catholic reality that can operate at the intersection between nature and the supernatural, without reducing either. To put it differently, de Lubac (like Blondel before him) claims that to end the crisis between reason and faith, or the secular state and Catholic religion, we need to keep the immanent order and the transcendent together as one in their irreducible and inseparable distinction from one another. This perspective, further deepened by theologians before the Council Vatican II and ultimately absorbed 
within the conciliar documents of Vatican II, would become known as the universality of grace.

A similar yet distinct sacramental line of thought infused the work of several Anglican theologians and philosophers who have engaged the Eucharist through the concept of anamnesis (Gittoes 2008; Hunsinger and Moore-Keish 2015) 'Anamnesis' is the term used in Christianity to refer to the memorial character of the Eucharist. It has its roots in Jesus's words at the Last Supper, "Do this in remembrance of me" (Luke 22:19). This statement, mentioned during the Eucharistic liturgy, maintains a certain degree of ambiguity, since 'anamnesis,' or 'remembrance,' or 'memorial,' is not simply a subjective perception or a passive process, rather one by which the faithful can actually participate to the Paschal mystery. Moreover, the anamnesis is referring to the idea that Christ is really present in the Eucharist and that his sacrifice is re-presented in the same way in which the sign points to a reality that is really present in the sign. To put it differently, the Eucharist is a sign that points to and participates in Christ. This is the difference between a symbol, which points but do not participate to the reality it pints to, and a sacrament, in which the sign participates in the reality it points to. In this terms, it is possible to say that the presence of Christ in the Eucharist in real in the sense of sacramental ontology, that is, of participatory ontology. Anglican theologians and philosophers such as Temple, Macquarrie, and the already mentioned Milbank and Boersma deny a sacramental ontology which is fleshy but accepting a real spiritual presence in the Eucharist.

The topic of anamnesis serves this article in two ways: first, it shows how sacramental ontology is a shift in theology that goes well beyond the wide but limited sphere of Catholicism. The Anglican (and Archbishop of Canterbury from 1942 to 1944) William Temple used the term 'sacramental universe' in the early part of the 20th century. In the 19th and last of his Gifford Lectures (1932-1934, University of Glasgow), Temple articulated a cosmology in which the physical points beyond itself to the mystery of the sacred. The notion that all things, words, and events reveal the presence of God, that the material reality is a sensible sign that manifest God's grace, is recovered and addressed in terms of sacraments by another Anglican theologian, John Macquarrie, in his work A Guide to the Sacraments (Macquarrie 1998). In the recent book of Julie Gittoes, the contribution of the Anglican tradition to a modern yet rooted in the patristic understanding of the anamnesis is offered (Gittoes 2008, pp. 136-39). The second way the topic of anamnesis serves this article is its direct connection between the notion of 'anamnesis,' or 'remembrance,' or 'memorial,' and that of 'memory.' Memory as a social category has received increasing attention in the field of history to the point that a theorist has openly argued about the emergence of memory in historical discourse (Klein 2011, pp. 112-37). The emergence of collective memory as a category of historical discourse and the investigation of memorial consciousness can be found in works such as Watergate in American Memory of sociologist Michael Schudson, History as an Art of Memory of historian Patrick H. Hutton, and History and Memory after Auschwitz of intellectual historian Dominick LaCapra (Schudson 1992; Hutton 1993; LaCapra 1998). The difference between these works and those of Anglican theologians such as Edward Pusey and Brian Douglas, however, is that with the former 'memory' takes a cultural inclination, while with the latter it assumes an ontological twist. Pusey was a 19th century theologian who, in the opinion of Douglas, anticipated modern Eucharistic theology (Douglas 2015). Pusey wanted to revive the sacramental understanding of the Eucharist. He rejected scientism but argued that science and theology have their own methods and in relation to Scripture that history should not be the judge but theology. By giving priority to theology over history when it comes to memory, he was simply giving expression of his moderate realist sacramental theology.

\section{Target}

If the origin of sacramental ontology as a concept refers to a situation of dualism between the reign of nature and the supernatural, the use of this concept today refers to a condition of radical immanentism. To put it differently, if the situation from which the 
recovery of a sacramental view of reality emerged was the dualist thesis of the two-story universe, the application of that view today is related to a form of historicism emphasizing the temporal upon the transcendental. Once again, de Lubac provided the guidelines. In his Preface to 1965 The Mystery of the Supernatural, de Lubac warned his readers that "the tide of immanentism is growing irresistibly" (de Lubac 2008, p. XXIV). He added that "the dualist ... thesis has finished its course," and now we face the challenge of the "doctrines of immanentism." He clarified at this point that

it is chiefly a question of "historical" immanentism, concentrating completely upon history, and envisaging the end of its development as a "universal reconciliation" which, both in itself and in the means needed to achieve it, would exclude everything supernatural (de Lubac 1998, p. XXXV).

For de Lubac, 'historical immanentism' stands for Marxism, which lacks a transcendent goal. In Catholicism, he had already suggested that Christianity held the corrective to two views of human existence: an ahistorical escapism in which the goal is to flee the world and the historical immanentism of Marxism (de Lubac 1988, pp. 140-41). In Catholicism, de Lubac made little effort to explicate this second stream of thought or philosophies of historical progress that underlay it. The pressing need was to assert the social and historical dimensions of Catholicism in the face of a growing spiritual individualism. During and after the Council Vatican II, however, de Lubac more directly emphasized the narratives of history within atheistic immanentism, including but not exclusively understood as Marxism. The conception of history advanced by historical immanentism is one that lacks transcendence. But history correctly understood, he believed, unites history and transcendence. Rebutting the view of an immanent order reduced to or nullified by the transcendent, or of a transcendent addendum to the immanent order, de Lubac suggested recognition of such an immanent order as insufficient to itself and conserved and affirmed as an integral part of the larger structure. Once again, he ultimately bridged the gap between modernity and Christianity through a re-articulation of the relationship between nature and grace.

In the decades since his death, interest in de Lubac's work, including his work on theology of history, has not faded. Initially, scholarship on de Lubac was limited to the effort of Catholic theologians. Increasingly, the scholarship on him has expanded outside Catholic theologians, including authors of Protestant and Anglican traditions who appeal to de Lubac's theology as a resource for ecumenical engagement and for the renewal of their own theological traditions. Among these authors, Anglican theologian John Milbank is particularly relevant here: he engages de Lubac with his own postmodern theological vision. Milbank is especially concerned with atheist immanentism and argues that

Transcendence saves all cognitive appearances as well as all ontological realities. By contrast, atheist immanentism is the doctrine of damnation of some for a while and in the end the eternal damnation of all and everything (Milbank 2005a, 2005b).

While de Lubac addresses the absence of transcendence in atheist immanentism as a challenge to the Church's tradition of reading history spiritually, Milbank understands it as a demonstration of nihilism. Milbank peculiarly links the absence of transcendence in atheist immanentism with nihilism. He notes that modern immanentism is post-Christian in character because it "has to think creation out of nothing without God, a nothing that is self-generative. This is why the shadow of nihilism is a post-Christian shadow" (Milbank 2011). With other Anglican and Evangelical theologians, Milbank believes that the challenge of nihilism in the socio-political realm consists of a straight choice between either embracing nihilism or embodying salvation (Milbank 2006; Milbank 1997a; Pickstock 1998).

But what exactly does Milbank have in mind when he describe modern immanentism as "creation out of nothing ... a nothing that is self-generative?" And how does it affect the enterprise of history? In the next few pages, I will try to unpack Milbank's cryptic 
remark and answer the second question. Usually historians learn that their profession was born in the 19th century from a desire to replace theology with science. An epistemological shift moved the meaning of ideas and events from divine will or natural law to historical context, replacing suprahistorical truths with historical truths (history reveals truth, in Hegelian terms). These historical truths, relative to specific times and places as they may be, can be taken seriously, although discounted to partial, contingent, incremental truths, as historicism relies on the integrity of the historian and the reality of the past. A synthesis of German Romanticism and French Enlightenment forged scientific history as we know it. For most historians, historicism's discovery of absolute historicity concerned the rejection of the 'extrinsicism' that places the absolute outside of the existential conditions of the one concrete order of history, and an acceptance of a secular 'intrinsicism' that removes the absolute from the one concrete order of history. In other words, the scientification of history expelled theology from the discipline. Further developments in the field provided an essential and durable philosophical foundation to historians' scientific ambitions to the point that today, although questioned from multiple angles, presumption of scientific historiography seems to hold. Not many historians pay close attention to theory, as they assume history is a practical discipline that deals with archives, books, and other artifacts. Among the few historians who do consider carefully the intellectual status of their discipline, however, a majority would agree on a sort of softer version of scientific history. They would probably accept some level of subjectivity on the part of the historian in order to protect a higher degree of objectivity of the past. As a result, the more innovative forms of historical methods crafted by historians these days-linguistic and cultural studies, French Annales, and so on-result in various configurations of 'realism.' Only a small minority of the scholars would mount the case for a different status of their discipline, claiming that history does not retain any trace of objectivity.

As a matter of fact, postmodernist forms of history validate a far more subversive degree of relativism. While historicism introduced a moderate form of relativism, truths relative to particular times and places once history conserves the claim of rigorousness and professionalism ('scientific history'), postmodernism denies historical truths, truths grounded so firmly in their historical context, implying the futility of the historical enterprise. Historians Anthony Molho and Gordon Wood once predicted no future relevance to postmodernism in history. They argued that postmodern relativism "is so destructive of all historical reconstruction" that "it is not likely to have a lasting effect on the writing of history in the United States" (Molho and Wood 1998, p. 12). Professors Molho and Wood echoed a well-established sentiment in the discipline, that is, American historians are genuinely and instinctively suspicious about a certain kind of relativism-postmodern relativism. ${ }^{7}$ Both contended that postmodernism disrupts the scientific essence of their profession and potentially alters the very character of their identity.

Scientific historians assume that there is a level of certainty written in the very fabric of reality that timelessly presides over our lives, while postmodernism argues that historians have given this status of certainty to these structures by depositing paradigmatic examples in an archive, turning them from empirical claims into object. Historians have seen the dismissal of the scientific approach as a gateway to historical investigations that would be merely subjective or imaginary, perhaps just inside historians' heads. ${ }^{8}$ Historians see postmodernism as an ultimate attack on the notion of the absolute and the possibility of

7 In the context of history and faith, Marsden, Kuklick, Hart, and Wells argue that postmodern epistemology is dominant in history. McClay doubts it and maintains that "the reigning mindset of the mainstream academy remains overwhelmingly secular-positivist" (see Marsden 1997; Kuklick and Hart 1997; Wells 1998; McClay 1997, p. 12). An informative overview of how the rank and file of historians in the United States have thought about epistemological questions is Novick (1988). Normal J. Wilson offers a sympathetic introduction to the most recent theoretical literature in Wilson (1999). Gertrude Himmelfarb presents a critique of postmodernism from a Christian perspective in Himmelfarb (1992).

8 Theorists such as Joyce Appleby and Gordon Wood have branded this evolution in terms of democratization of the discipline. History becomes populated of many languages. Authors other than white or male entered the discipline, historical claims were no longer universal, and postcolonial, postmodern, racial discourses initiated (see Appleby et al. 1994, p. 3). This democratization is welcome as long as it does not affect the universal claim of scientific objectivity. Historians were invited to imagine scientific "historicities as some among many," declares Kerwin L. Klein, "historicities in both conversation and conflict with a profusion of narrative traditions" (see Klein 2011, p. 111). 
truth. For some, scientific history is fighting for its right to defend the existence, if not of suprahistorical truths, at least of historical truths, or truths relative to particular contexts. Truly, postmodernists' dismisses the validity of historical truths as well as the possibility of historians' integrity and any access to the reality of the past. This anti-realistic attitude of postmodernism in history fuels criticism. Yet, this specific postmodern attack to historicism limits its effects to epistemology. A powerful challenge to history comes from ontological nihilism, which is not intending to reject and oppose historicism in terms of the relative, but rather in terms of the ephemeral.

As a theoretical approach, nihilism is the manifestation within the discipline of history of a nihilistic cultural package that has triumphed and reigns ubiquitous. To put it differently, nihilism is not internal to history as a discipline, rather it is the essential substratum of the culture of these days. Like gravity, it is everywhere, and everywhere it is invisible. The mistake resides on the side of historians who examine nihilism while wearing philosophical glasses, missing the culturally embodied aspects of the problem. Nihilism is an entire cultural package with a complex array of ontological and metaphysical foundations affecting every dimension of our life, including history. Nihilism is not attaching the objectivism of history, but reducing it and rendering it meaningless. The nihilistic character of the culture of this age does not claim that the past is subjective; it celebrates the liberation of all from the ontological fixity of the past. Nihilism is the essence of the culture of our time. So, although historicism remains the dominant approach applied by professional historians, nihilistic modernism is already the signature characteristic of how contemporary culture addresses the historical enterprise.

Nihilism is the action guided and shaped by the so-called nihilation of things, i.e., the belief that no objective, immutable things exist. Nihilism, philosopher Emanuele Severino argues, is "the persuasion that every thing is ephemeral, insofar as it is subject to birth and death" (Severino 2015, p. 13). He describes how nihilism turns the world on its head:

things, insofar as they are things, do not exist by necessity. For the philosophical tradition, divine things exist by necessity; but they exist by necessity not insofar as they are things, but insofar as they are divine. But then, in its deepest ... essence, contemporary philosophy shows that divine things cannot exists (Severino 2015, p. 14).

Severino makes clear that a main effect of nihilism exists in making inconceivable the existence of permanent objects. As a matter of fact, immutable objects are, in effect, permanent values (ethical, natural, etc.) raised with the logic of the remedy, to defend individuals and societies from the 'becoming,' the historical character of the becoming of things. ${ }^{9}$ Having Severino in mind, the dynamics between 'immutable' and 'becoming' can be translated in the realm of history: the past as an objective reality is a value that historians raised to defend themselves, their discipline, and an eventual order of society perceived as necessary. The past is not changing; the past is a permanent reality. It does not become. In fact, if the past really becomes, it is time in motion, the transitory figures of ideas and events that are located in the historical flux. In such a situation, the primary reality of the flux of time - what becomes-exercises a centrifugal force against the artificial edifice of historicism through which the "immutable" vanishes. Not only that: society at large, to paraphrase Nietzsche, becomes a chaos (Nietzsche 1961, p. 107). ${ }^{10}$ Thus, historians maintain that history is possible only if the 'becoming' is corrected with the notion of realities, essences, and institutions that cannot become. The abandonment of the 'immutable' and the choice of the 'becoming' is the folly that scientific history is trying to avoid. Faced with the radical nihilism of the motor of becoming, historicism has evoked the ordering and governing principles of time, including the objectivity of the past.

9 The original quote goes as follow: "The West has invoked the immutables to save itself, that is, to dominate the eruption of becoming" (see Severino 1979, pp. 18-19).

10 Here is the original quote: "How, In Other Words, Could a Chaos Become a Cosmos?" 
The fundamental definition of nihilism, Severino argues, is the persuasion that "things-that is, entities, non-nothing-are nothing" because they are ephemeral (Severino 2015, p. 39). They are for a while, and then become nothing. Sometimes it seems that historians operate on the assumption of a dual structure of reality: the being and the becoming. Their faith in the 'immutable' causes them to see the 'becoming' as a simple mutation, a matter of forms and sensibilities. The binary distinction between the mutable and the immutable is the implicit assumption of historians, who can continue to investigate the unchanging structure of the past while recognizing a landscape that is constantly in flux. Thus, the reality of the past persists despite the unstoppable dynamism of time; it remains untouched by all of that flux and provides stability and certainty. By postulating the 'immutable' as the underlying reality of history, historians have segregated the evidence of 'becoming' at the level of mere appearance. If the past is understood as the accumulation of what the 'becoming' is ineffective with, if the past is outside the domain of the 'becoming,' then the 'becoming' no longer has that ontological character that postmodernism has recognized. If the 'becoming' is understood as a process in which the past is unchangeable, outside the domain of the 'becoming,' then the 'becoming' stands in front of the past as the face of a God. Indeed, the immutability of the past presents the most characteristic features of the divine, indeed its untouchability. If there is a past in these terms, then this unchangeable past implies the impossibility of 'becoming.' But there is not a dual structure of reality: the being and the becoming. There is only the 'becoming' that constructs and deconstructs reality in a permanent process of nothing that turns into something and vice versa. 'Becoming' is not mutation, but instead change in the order of ontology. Severino points out that the 'becoming' dissolves everything that claims to possess immutability because the former operates at the deepest dimension of reality of the latter: "True nihilism is essentially unconscious" (Severino 2015, p. 8).

Nihilism is the ethos, the dwelling-place of this age. If we mention the "death of the past," to reverberate J. H. Plumb, is because the essential substratum of the culture of these days shows that the only possible truth is the becoming of everything (Plumb 1970, pp. 11-17). Severino argues that in the spirit of our times no 'immutable' can exist. There exists the concrete evidence that we live in a reality in perpetual becoming, in which 'becoming' is what becomes, what comes to life and comes to an end, what comes from nothing and returns to nothing. People, cities, events, and concepts enter the stage of history and then, inexorably, leave it, and everything is left behind. The "death of the past" is the denial of the "immutable," the fixity of the past, and thus any objective truth about the past (Severino 2015, p. 8). Historians recreate the past and can annihilate it at will. To paraphrase Severino, the past is nothing other than an absolute availability to be produced and destroyed. ${ }^{11}$ Not surprisingly, history according to postmodernism tends to sink into literature, because literature is compatible with the 'becoming.'

I should be clear now about what Milbank intends when he talks about modern immanentism as "creation out of nothing ... a nothing that is self-generative," and how it affects the whole enterprise of history. If Milbank and other Christian scholars who share his insight are correct, ontological nihilism poses a much more dangerous threat to history than does mere relativism. Historicism can still dominate the discipline, historians can debate which degree of subjectivity agree to accept without risking compromise of the coherence of the order of things, but history has been revealed by nihilism to be indifferent and arbitrary. Where we once lived in a world steeped in historical significance, now we live in a world where things simply happened. Where once the meaningfulness of history was an unquestioned certainty, the very foundation of social order, now we must continually struggle to make our past meaningful, and do so, moreover, without the sanction of objectivity. To say that history is seen as nihilistic is to say that it is indifferent to human concerns. Where historicism revealed a world as meaningful, the fundamental

11 The original quote goes as follow: "Which is to say that a thing is nothing other than an absolute availability to be produced and destroyed; a thing not available in this way is unreal" (see Severino 2015, p. 6). 
meaning of nihilism applied to historical enterprise is that human history is arbitrary and meaningless. If there is no history in the objective sense, then there is no direction in the unfolding of events or of historical structures.

\section{Final Remarks}

From this brief inquiry into the origins and motivations of the sacramental ontology authors, a few points can be extract. First, sacramental ontology comes from intellectual circles that are on amicable terms with modernity and open to incorporating at least some elements of modernity into Christian tradition. Second, the development of the concept of sacramental ontology is a result of a struggle internal to the Christian intellectual world and was not generated as a reaction to secularism. As a matter of fact, the source of that dangerous dualism, as de Lubac branded it, is bad theology, not Enlightenment. Sacramental ontology is part of a remedy of a deviation that occurred within the realm of Christian thought. Third, the adoption of this concept of sacramental ontology works as an antidote not against science but rather against the challenge of ontological nihilism, the idea that all is ephemeral. In the first chapter of his book, Gregory attacks the widespread modern perception that science and religion are incompatible. ${ }^{12}$ At the same time, he protests the effects of ontological nihilism, by arguing, in regards to the present, that secularism and scientism are "subverting modernity's most fundamental assumptions from within" in that they are undermining and preventing "the articulation of any intellectually persuasive warrant for believing in the realities presupposed by liberal political discourse and the institutional arrangements of modernity: that there are such things as persons, and that they have such things as rights" (emphasis added) (Gregory 2012a, p. 376). When he criticizes science, it is not a liberal understanding of science he has in mind, rather the radical forms of scientism of these days, those forms like transhumanism and biogenetics of the new scientific naturalistic worldview. Gregory claims that the basis of liberalism cannot sustain itself "in research universities and in the public sphere" against the rise of scientific naturalism (and here he addressed transhumanism as a moral philosophy) in which "'persons' [...] 'rights' [and] 'dignity' are fictions [...]" (Gregory 2012a, p. 381). When he attacks science, he thinks of a science already located in a post-liberal world. a response to the critiques against the general outlook that he provides on the contemporary situation, Gregory also says:

It remains to be seen how well liberalism's alleged 'pragmatic, negative consensus' can hold up in societies whose members lack shared substantive values, disagree sharply over matters of central importance for human life, and are increasingly equipped with technological means to pursue unprecedented aims that serve the divergent desires. Indeed, how well is it holding up now? (Gregory 2012b, p. 419).

A possible interpretation of the above sentence reads as follows: the entire debate on sacramental ontology and history needs to be re-thought in these terms, that is, whether historians should maintain the separation between immanent and transcendental realities or try to build bridges between the two in a context in which Christians feel more equipped than seculars in facing the crisis of western historical consciousness and the mounting nihilism ignited by the technoscience.

Funding: This research received no external funding.

Institutional Review Board Statement: Not applicable.

Informed Consent Statement: Not applicable.

Data Availability Statement: Not applicable.

12 Kathleen Crowther maintains, however, that Gregory's statements about science throughout the book might best be described as ambivalent (Crowther 2012). 
Acknowledgments: I thanks the two anonymous reviewers for their suggestions, which have made this article more consistent and organized.

Conflicts of Interest: The author declares no conflict of interest.

\section{References}

Appleby, Joyce, Lynn Hunt, and Margaret Jacob. 1994. Telling the Truth about History. New York and London: Norton. Appold, Kenneth G. 2013. A World Undone: Brad Gregory's critique of the Reformation. Pro Ecclesia 22: 395-99. [CrossRef]

Blondel, Maurice. 1950. L'Action: Essai d'une Critique de la vie et d'une Science de la Pratique, Reprint ed. Paris: Alcan, Paris: Presses Universitaires de France. First Published 1893.

Blondel, Maurice. 1909-1910. La 'Semaine Sociale' de Bordeaux. Annales de Philosophie Chrétienne 159: 268-71.

Blondel, Maurice. 1956. Les Premiers Écrits de Maurice Blondel. Paris: Presses Universitaires de France, Volume 2, pp. 149-245.

Blondel, Maurice. 1964. Letter on Apologetics and History and Dogma. Translated by Alexander Dru, and Illtyd Trethowan. London: Harvill Press.

Boersma, Hans. 2009. Nouvelle Theologie and Sacramental Ontology: A Return to Mystery. New York: Oxford University Press.

Boersma, Hans. 2011. Heavenly Participation: The Weaving of a Sacramental Tapestry. Grand Rapids: Eerdmans.

Cavanaugh, William T. 2013. The modest claim of an immodest book. Pro Ecclesia 22: 406-12. [CrossRef]

Chappel, James. 2013. An Intended Absence? Democracy and The Unintended Reformation. September. Available online: http://blogs.ssrc.org/tif/2013/09/05/an-intended-absence-democracy-and-the-unintended-reformation/ (accessed on 13 August 2019).

Crowther, Kathleen. 2012. Review of Gregory, Brad S., The Unintended Reformation: How a Religious Revolution Secularized Society. H-HRE, H-Net Reviews. September. Available online: http:/ / www.h-net.org/reviews/showrev.php?id=35103 (accessed on 3 August 2020).

de Lubac, Henri S. J. 1998. The Mystery of the Supernatural. Translated by Rosemary Sheed. Introduced by David L. Schindler. New York: Herder \& Herder.

de Lubac, Henri S. J. 2008. Augustinisme et Théologie Moderne, Oeuvres Complètes XIII. Paris: Cerf.

de Lubac, Henri. 1946. Surnaturel: Etudes Historiques. Paris: Aubier-Montaigne.

de Lubac, Henri. 1988. Catholicism: Christ and the Common Destiny of Man. San Francisco: Ignatius Press.

Douglas, Brian. 2015. The Eucharistic Theology of Edward Bouverie Pusey. Leiden and Boston: Brill.

Doyle, Dennis. 1990. Henri de Lubac and the Roots of Communion Ecclesiology. Theological Studies 60: 209-27. [CrossRef]

Gittoes, Julie. 2008. Anamnesis and the Eucharist: Contemporary Anglican Approaches. Farnham: Ashgate Publishing.

Gordon, Peter E. 2013. Has Modernity Failed? September. Available online: http:/ /blogs.ssrc.org/tif/2013/09/12/has-modernityfailed/ (accessed on 1 June 2020).

Gregory, Brad S. 2012a. The Unintended Reformation: How a Religious Revolution Secularized Society. Cambridge: Belknap Press of Harvard University Press.

Gregory, Brad S. 2012b. Response to Matthew Lundin's Review. Christian Scholar's Review 41: 415-19.

Haight, Roger D. 1974. The Unfolding of Modernism in France: Blondel, Laberthonnière, Le Roy. Theological Studies 35: 632-66. [CrossRef]

Himmelfarb, Gertrude. 1992. Tradition and Creativity in the Writing of History. First Things 27: 28-36.

Hunsinger, George, and Martha L. Moore-Keish. 2015. Twentieth-Century and Contemporary Protestant Sacramental Theology. Oxford: Oxford University Press.

Hunter, Ian. 2013. The Return of Sacred History. September. Available online: https:/ / tif.ssrc.org/2013/09/10/the-return-of-sacredhistory / (accessed on 23 September 2019).

Hutton, Patrick H. 1993. History as an Art of Memory. Hanover: University of Vermont Press.

Jones, Andrew Willard. 2017. Before Church and State. A Study of Social Order in the Sacramental Kingdom of St. Louis IX. Steubenville: Emmaus Academic Press.

Kahn, Victoria. 2013. Get Over It. September. Available online: https://tif.ssrc.org/2013/09/16/get-over-it/ (accessed on 12 May 2020)

Kasper, Walter. 1989. Theology and Church. London: SCM Press.

Klein, Kerwin L. 2011. From History to Theory. Berkeley: University of California Press.

Kuklick, Bruce, and Darryl G. Hart, eds. 1997. Religious Advocacy and American History. Grand Rapids: Eerdmans Publishing Co.

LaCapra, Dominick. 1998. History and Memory after Auschwitz. Ithaca: Cornell University Press.

Lilla, Mark. 2013. From Wittenberg to Wal-Mart. New Republic 243: 47-52.

Lundin, Matthew. 2012. The Unintended Reformation-A review essay. Christian Scholar's Review 41: 407-13.

Macquarrie, John. 1998. A Guide to the Sacraments. New York: Continuum.

Marlé, René. 1960. Au coeur de la Crise Moderniste: Le Dossier Inédit d'une Controverse. Paris: Aubier.

Marsden, M. George. 1997. The Outrageous Idea of Christian Scholarship. New York: Oxford University Press.

McClay, Wilfred M. 1997. Why the Academy Needs Christians. Books and Culture, May/June 12.

Milbank, John. 1997a. The Word Made Strange: Theology, Language, Culture. Oxford: Wiley-Blackwell.

Milbank, John. 1997b. Theology and Social Theory. Oxford: Blackwell. 
Milbank, John. 2005a. Henri de Lubac. In The Modern Theologians: An Introduction to Modern Theology Since 1918. Edited by David F. Ford. Malden: Blackwell.

Milbank, John. 2005b. The Suspended Middle: Henri de Lubac and the Debate Concerning the Supernatural. Grand Rapids: Eerdmans.

Milbank, John. 2006. Theology and Social Theory: Beyond Secular Reason, 2nd ed. Malden: Blackwell Publishing.

Milbank, John. 2011. Stanton Lecture 3: Immanence and Number. Unpublished lecture, University of Cambridge, Cambridge, UK, February 2.

Molho, Anthony, and Gordon S. Wood. 1998. Imagined Histories. In American Historians Interpret the Past. Princeton: Princeton University Press.

Nietzsche, Friedrich. 1961. How, In Other Words, Could a Chaos Become a Cosmos? In Philosophy in the Tragic Age of the Greeks. Washington: Regnery Gateway.

Novick, Peter. 1988. That Noble Dream: The "Objectivity Question" and the American Historical Profession. New York: Cambridge University Press.

Pabst, Adrian. 2013. Secular Supercessionism and Alternative Modernity. Available online: https://tif.ssrc.org/2013/09/24/secularsupercessionism-and-alternative-modernity/ (accessed on 23 June 2020).

Pickstock, Catherine. 1998. After Writing: On the Liturgical Consummation of Philosophy. Oxford: Wiley-Blackwell.

Plumb, John H. 1970. The Death of the Past. Boston: Houghton Mifflin.

Schudson, Michael. 1992. Watergate in American Memory: How We Remember, Forget, and Re-construct the Past. New York: Basic Books.

Scott, William A. 1966. The Notion of Tradition in Maurice Blondel. Theological Studies 27: 384-440. [CrossRef]

Severino, Emanuele. 1979. Gli Immutabili, il Niente, il Caso. Milan: Adelphi Edizioni.

Severino, Emanuele. 2015. Nihilism and Destiny. Edited by Nicoletta Cusano. Milan: Mimesis International.

Taylor, Charles C. 2007. A Secular Age. Cambridge: Harvard University Press.

von Balthasar, Hans Urs. 1992. The Theology of Karl Barth. Translated by S. J. Edward T. Oakes. San Francisco: Ignatius Press, p. 341. First published 1951. (In German)

Ward, Michael. 2007. Planet Narnia: The Seven Heavens in the Imagination of C. S. Lewis. New York: Oxford University Press.

Wells, Ronald A., ed. 1998. History and the Christian Historian. Grand Rapids: Eerdman's Publishing Co.

Wilson, Normal J. 1999. History in Crisis? Recent Directions in Historiography. Upper Saddle River: Prentice-Hall. 